28. Crioceris; Chrysomelide. Chrysomelide (Fabr., Oliv., Latr.)

29. Altica; Chrysomelide. Chrysomelide (Fabr., Oliv., Latr.)

30. Galeruca; Chrysomelide. Chrysomelide (Oliz., Latr., Fabr.)

31. Chrysomela; Chrysomelide. Chrysomelide (Linn., \&uc.)

32. Mylabris; Bruchide. Meloide (Fabr., Oliv., Latr.)

33. Rhinomacer; Attelabide. Rhinomaceride (Latr.)

34. Curculio; Curculionide. Curculionide (Limn., \&oc.)

35. Bostrichus; Bostrichide. Bostrichide (Oliv., Latr.) Scolytide (Fabr.)

36. Clerus; Cleride. Cleride (Fabr., Oliz., Latr.)

37. Anthribus; Anthribide. Anthribide, Oliv., Latr.

38. Scolytus; Scolytide. Scolytide (Otiv, Latr.) Carabide, Fabr.

39. Cassida; Chrysomelide. Chrysomelide (Limn, \&oc.)

40. Anaspis; Mordellide. Mordellide (Latr.)

4I. Coccinella ; Coccinellide. Coccinellide (Limn., \&6.)

42. Tritoma; Mycetophagide. Erotylide (Fabr., Eoc.)

43. Diaperis; Tenebrionide. Tenebrionide (Oliv., Latr.)

44. Pyrochroa; Pyrochroide. Pyrochroide (Fabr., Oliv., Latr.)

45. Cantharis; Meloide. Meloide (Otiv., Latr.) Telephoride (Linn.,. Fabr.)

46. Tenebrio; Tenebrionide. Tenebrionide (Limn., 心e.)

47. Mordella; Mordellide. Mordellide (Lim., \&c.)

48. Notoxus; Anthicide (Fabr., Oliv, Latr.) Cleride, Fabr.

49. Cerocoma; Meloide. Meloide (Fabr., Oliv., Latr.)

5o. Staphylinus; Staphylinide. Staphylinide (Limn, Ooc.)

51. Necydalis; Telephoride. Cerambycide (Linn., Oliv., Fabr.). Oedemeride (Fabr.)

52. Meloe; Meloide. Meloide (Linn., Evc.)

\title{
DISCREPANCIES IN RECENT LISTS OF LEPIDOPTERA.
}

\author{
IBY W. F. KLRBY, ENGLAND.
}

The opponents of the law of priority in nomenclature have taken occasion, both in England and America, to argue against the restoration of obsolete names, on the ground that the names employed in $\mathrm{my}$ Catalogue of Diurnal Lepidoptera do not always harmonize with those used in Staudinger's Catalogue of European Lepidoptera. Although this. 
argument looks plausible at first sight, a little reflection will probably convince many that it is baseless. We may leave genera out of the question now, as Staudinger has not attempted to grapple with the difficulties which they present; but as regards species, it must be remembered-rst, that Staudinger starts from $\mathrm{I}_{75} 8$, instead of ${ }_{17} 6_{7}$, and that I should have done the same had I investigated the question fully when I commenced my work; and and, that Staudinger, working at European Lepidoptera only, was necessarily better acquainted with the special literature relating to them than myself. Had I selected $175^{8}$, and possessed Werneburg's Beitrage zur Schmetterlings kunde at the time I was writing my own Catalogue, or had Staudinger's new Catalogue been published in time for me to verify the references contained in it, I think I may say that many of the alleged discrepancies would have disappeared, although, in some cases, I may have made use of materials which. Staudinger does not appear to have employed, or may have seen reason to disagree with him as to the determination of certain species. Unless two authors have exactly the same materials to work with, or one copies from the other, no rules will be sufficient to insure their absolute agreement in every case; but by the strict law of priority, the chances of disagreement are reduced to a minimum.

\section{MICRO - LEPIDOPTERA.}

BY V. T. CHAMBERS, COVINGTON, KENTUCKY.

(Continued from page 170.)

ANTISPILA.

A. ampelopsisella. N. sp.

In the preceding paper on this genus I mentioned that I had found' the larva of this species mining the leaves of Ampelopsis quinquefolia. Since that paper was placed in the hands of the Editor, many months. ago, $I$ have succeeded in rearing it from the mine.*

* The specimen mentioned in that paper as having been bred from the Long* worth grape-vine, is now too much denuled for satisfactory comparison with this species, but I believe it to be the same ; certainly it is not any of the other known. American species, and I have never met with it except in the Longworth grape leaf. 